\title{
Don Quijote en manos de Goya
}

Don Quixote in Goya's hands

Jesús Pérez-Magallón

McGill University

CES.XVIII, núm. 26 (2016), págs. 155-178 


\section{RESUMEN}

Este ensayo explora las dos intervenciones de Goya en el mundo de Don Quijote: el grabado que le solicitó la Academia para su magnífica edición de 1780 — que nunca fue publicado - y el dibujo que hizo Goya en la última página de uno de sus cuadernos (el álbum F), dibujo que hoy se encuentra en el British Museum, pero que fue copiado y grabado por Bracquemond hacia mediados del siglo XIX. El ensayo se inicia con una visita a la biografía del pintor y se detiene en algunos aspectos tal vez conflictivos de la misma, para pasar después a la presentación y análisis de los grabados con el objetivo de proporcionar alguna explicación de sus diferentes avatares y de sus cuestionables aportaciones.

Palabras clave:

Francisco de Goya, Don Quijote, grabados, dibujos, Cervantes, recepción, iconografía.

\section{Abstract}

This paper explores two Goya's images on Don Quixote: first, the drawing requested by the Spanish Royal Academy for the 1780 edition of the novel, etched by Frabregat that was never published. Second, a drawing on the last page of his album F. The original is held at the British Museum, though it was copied and etched by Bracquemond in the $19^{\text {th }}$ century. My paper revisits Goya's biography and particularly his inclusion among the afrancesados, a conflicting topic about his life. Then I analyze both images in order to provide some explanation on their significance and transcendence.

KEY WORDS

Francisco de Goya, Don Quixote, etchings, drawing, Cervantes, reception, iconography.

Recibido: 9 de junio de 2016. Aceptado: 26 de septiembre de 2016. 
Cada acercamiento a Goya —o a cada ángulo de Goya, y son muchos sus ángulos- presenta riesgos y peligros, aunque también estímulos muy dispares. Es frecuente iniciar tales acercamientos con una a veces breve recapitulación biográfica, estrategia que en el caso de Goya abre muchas posibilidades. En un curso sobre Goya que he dado más de una vez siempre empiezo con algo tan elemental como sus fechas de nacimiento y muerte, es decir, 1746 y 1828. Porque eso me permite afirmar con convicción que la vida de Goya contempla acontecimientos sin la menor duda de la mayor trascendencia, en primera instancia, para la historia de Europa occidental y, más específicamente, de España; pero, en segunda, no solo para el viejo continente, pues desde la revolución americana (1769) hasta las independencias hispanoamericanas podríamos decir que asistimos a un cambio sustancial en la geopolítica del mundo llamado occidental. El hecho de que un historiador de las mentalidades tan solvente como Francisco Sánchez-Blanco titulara uno de sus libros La Ilustración goyesca. La cultura en España durante el reinado de Carlos IV (1788-1808)1 nos permite hacernos una idea del valor icónico que la figura del pintor ha llegado a ocupar en el imaginario español o tal vez la influencia generalizada de algunas ideas y tácticas de Ortega y Gasset. Pero el final que Sánchez-Blanco atribuye a ese periodo, 1808, nos sitúa de pleno en la crisis social, cultural y política que conlleva las guerras napoleónicas y, por tanto, el enfrentamiento con el ejército francés y las autoridades impuestas por Napoleón. Y es curioso, porque Goya va a formar parte de ese círculo llamado «los afrancesados», circunstancia existencial que, además de marcar una fase larga de su vida, habla alto y claro sobre sus posicionamientos políticos. Y porque es ese Goya, primero bajo los gobiernos de Floridablanca, Aranda y Godoy — con Carlos III y Carlos IV—, pero luego bajo José I y Fernando VII —dejando de lado el Trienio Liberal—, el que nos va a servir de referencia para explorar una forma de recepción del Quijote - la de Goya - tan particular como su propia existencia.

Preguntarse qué legitimidad quedaba en la España de 1808 tras los motines de El Escorial y de Aranjuez, y de las abdicaciones de Bayona ${ }^{2}$ es un gesto

1 Francisco Sánchez-Blanco, La Ilustración goyesca. La cultura en España durante el reinado de Carlos IV (1788-1808), Madrid, Consejo Superior de Investigaciones Científicas, 2007.

2 Véase, por ejemplo, Raymond CARR, Spain 1808-1975, Oxford, Clarendon Press, 1982, págs. 79-119. 
plenamente legítimo. En España, la familia real, sometida a una doble presión, la popular y la napoleónica, dio un espectáculo bochornoso en el que tanto Carlos IV como Fernando VII mostraron su catadura moral — capaz de resquebrajar cualquier lealtad-, es decir, su obvia disposición a venderle la patria al poderoso Napoleón, quien no dudó en colocar en el trono español a su hermano José ${ }^{3}$ Era un paso más — simbólico y de poder - del auge de la Francia revolucionaria (o más bien termidoriana) como potencia europea. La resistencia popular, que cierta corriente identifica con el comienzo de una revolución nacional ${ }^{4}$, no fue sino el movimiento de conservación y protección de la dinastía reinante pero, sobre todo, de los valores que se podían identificar con lo más casposo y rastrero de una tradición y una historia. Como analiza Manuel Sacristán al estudiar los escritos de Marx sobre esa España: «las Cortes de Cádiz no dispusieron ya de posibilidades revolucionarias; encerradas en un último rincón del territorio, las Cortes eran solo "la España ideal", mientras "la España real" se encontraba en las convulsiones de la guerra o estaba ya sometida por el invasor [...]. "En el momento de las Cortes, España estaba dividida en dos partes. En la Isla del León, ideas sin acción; en el resto de España, acción sin ideas" ${ }^{5}$.

Desde una muy discutible óptica, lejana en el tiempo y marcada por imperativos categóricos de orden moral, nada justificaba abandonar la fidelidad al rey de España. Pero, ¿por qué a Fernando en vez de a Carlos, o al revés? De todos modos, para quienes vivieron ese momento la cosa no debió de ser tan fácil, y aceptar a un nuevo rey nombrado por Napoleón tenía todas las apariencias de legalidad, excepto para una iglesia temerosa de que las medidas radicales que podían presumirse con la llegada del elegido del emperador acabaran con sus privilegios ancestrales. Como escribe Jean-René Aymes, si los afrancesados «se rallient au roi Joseph, c'est, en partie, pour ne pas légaliser le coup de force d'Aranjuez; la racaille, le "vulgo" a intronisé Ferdinand: son pouvoir porte un vice rédhibitoire» ${ }^{6}$. Maticemos que no solo el vulgo; también la aristocracia, o una buena parte de ella. El arzobispo Félix Amat, teorizando con cierta elegancia una realidad cutre y perdularia, había escrito que «Dios es quien da y quita los reinos y los imperios, y quien los transfiere de una persona a otra, de una

3 Véase Juan Mercader Riba, José Bonaparte, rey de España 1808-1813, 2 vols., Historia externa del reinado, Madrid, Consejo Superior de Investigaciones Científicas, 1971; Estructura del estado español bonapartista, Madrid, Consejo Superior de Investigaciones Científicas, 1983.

4 R. Carr, Spain, pág. 81; Santos Juliá, Historia de las dos Españas, Madrid, Taurus, 2004, págs. 21-22.

5 Manuel SACRistáN, «Marx sobre España», Papeles de Economía Española, 17 (1983), págs. 110-118, $<$ http://www.rebelion.org/noticia.php?id=112007>.

6 Jean-René Aymes, L'Espagne contre Napoléon. La Guerre d'Indépendance espagnole (1808-1814), Paris, Nouveau Monde, Fondation Napoléon, 2003, pág. 55. 
familia a otra familia y de una nación a otra nación o pueblo» ${ }^{7}$. Moratín, en el «Prólogo» a su fallida edición de Fray Gerundio de Campazas, alude a la situación de su momento hablando de «los altos designios de su providencia, que da y quita los cetros ${ }^{8}$, y en 1810 retoma esa idea en un soneto donde escribe: «el rayo de la guerra / rompa y trastorne llaves y corona ${ }^{9} »$. Y si los altos designios de la providencia pueden alterar las dinastías reinantes, también «el rayo de la guerra»—léase Napoleón— puede hacerlo. En ese contexto, frente a la España resistente contra la ocupación francesa, quienes confían en que el nuevo régimen lleve a cabo las reformas todavía pendientes pertenecen a la España legal, determinada en su forma por los trapicheos de los Borbones con Napoleón. Y esos que permanecieron en la legalidad de la letra son quienes pasaron a la historia como afrancesados.

Digamos que el problema afrontado por Miguel Artola cuando llevó a cabo su estudio sobre los afrancesados $(1953)^{10}$ y por Juretschke después $(1962)^{11}$ es que al hablar de ilustrados se está utilizando un calificativo de carácter intelectual en tanto que al hablar de liberales, absolutistas o conservadores se están empleando adjetivos políticos. Bajo el de los afrancesados se mezcla todo y todo cabe. En ese sentido, lo afirmado por Méndez Bejarano ${ }^{12}$ en 1912 y Suárez ${ }^{13}$ en 1950 respecto a la continuidad política que se da entre ilustrados, josefinistas y constitucionalistas gaditanos - y que en cierto sentido ya había sostenido, desde su óptica irónica indiscutible, Sebastián Miñano ${ }^{14}$ en 1820 — vino a ser cuestionado por Artola y reafirmado por Juretschke. Pero la continuidad ideológica, cultural y política — desde nuestro punto de vista, una realidad que no se presta a discusión - no anula una diferencia radical entre los individuos concretos: el posicionamiento institucional en relación al rey impuesto por Napoleón. Y esa es la diferencia que sirvió de base a historiógrafos y políticos posteriores para excluir definitivamente de la historia buena (conservadora o liberal) a los afrancesados, es decir, a quienes sirvieron, de un modo u otro, a José I. Desde luego, tanto el absolutismo fernandino - recordemos el título que fray

\footnotetext{
7 Citado en Hans JuRetschKe, Los afrancesados en la Guerra de la Independencia: su génesis, desarrollo y consecuencias históricas, Madrid, Rialp, 1962, pág. 46.

8 Los Moratines, ed. de Jesús Pérez-Magallón, 2 vols., Madrid, Cátedra, 2008, t. II, pág. 1364.

9 Los Moratines, t. II, pág. 907.

10 Miguel Artola, Los afrancesados, pról. de Gregorio Marañón, Madrid, Turner, 1976.

11 JuRETSChKe, Los afrancesados.

12 Mario Méndez Bejarano, Historia política de los afrancesados, Madrid, Librería de los Sucesores de Hernando, 1912.

13 Federico SuÁrez, La crisis política del antiguo régimen en España (1800-1840), Madrid, Rialp, 1950.

14 Sebastián Miñano, Lamentos políticos de un pobrecito holgazán acostumbrado a vivir a costa ajena, introd. de Valeriano Bozal Fernández, Madrid, Ciencia Nueva, 1968, pág. 71.
} 
Manuel Martínez: Los famosos traidores refugiados en Francia y convencidos de sus crímenes ${ }^{15}$ - como el conservadurismo decimonónico utilizaron a profusión el posible colaboracionismo con el invasor — simbolizado en la voz afrancesado que a su vez fue sinónimo de traidor- como arma arrojadiza contra sus adversarios políticos. Entre quienes atacaron a los afrancesados se contaban varios personajes que en otro tiempo habían sido tenidos por «profranceses» (o afrancesados), estilo Antonio de Capmany, Quintana o el reconvertido Jovellanos.

Julián Marías en «España y Europa en Moratín» supo plantear con agudeza el dilema al que tuvieron que hacer frente los ilustrados, todavía no escindidos según sus adscripciones políticas. Escribe Marías:

La situación de los «ilustrados» apenas tenía solución adecuada: si abrazaban la causa de la independencia nacional [o sea, enfrentarse con las armas a los invasores], esto los llevaba a una cooperación con fuerzas que lo que primariamente querían era la resistencia a las innovaciones de Francia, el mantenimiento del antiguo régimen en sus formas más reaccionarias [...] Pero, por otra parte, si querían salvar las innovaciones y la libertad, la tentación inmediata era la cooperación con los invasores, su aceptación por lo menos, y ello implicaba una abdicación de la dignidad nacional y de su propia independencia ${ }^{16}$.

Desde luego, como ya hemos dicho, esa «dignidad nacional» no había salido muy bien parada de las abdicaciones de Bayona, aunque también puede atribuirse un sentido esencialista y trascendente a la idea de la dignidad nacional que debía revelarse intuitivamente a cualquier «verdadero» español. Pero lo que me parece más significativo de ese grupo social es que no se encuentra in-between (en medio de) o sea entre unos grupos y otros, no está al margen de un grupo hegemónico y de otro marginal, sino que se encuentra fuera de cualquier grupo, en la periferia del conjunto de la colectividad nacional. En efecto, la derecha, el conservadurismo político, los tendrá siempre como un conjunto de traidores a los valores eternos e inmutables de la nación, emparentándolos subliminal o abiertamente con cualquier forma de liberalismo progresista; la izquierda, el progresismo, los verá siempre como unos traidores al proceso democratizador independiente del país, alejados del constitucionalismo gaditano y sus periódicas reencarnaciones, asociados al absolutismo. Así, ser afrancesado es estar fuera de todo, es no tener ningún amarre

15 Manuel Martínez, Los famosos traidores refugiados en Francia y convencidos de sus crímenes, y justificación del real decreto de 30 de mayo, Madrid, Imprenta Real, 1814.

16 Julián Marías, «España y Europa en Moratín», en Los españoles, Madrid, Revista de Occidente, 1971, págs. 136-137 
en ningún sector social, es haber perdido cualquier posibilidad de formar una parte aceptable y asumible de la historia. Desde luego, la historiografía es resbaladiza y manipulable, por lo que uno lee sin rubor textos sobre Goya en los que se corre un tupido velo sobre su afrancesamiento ${ }^{17}$, lo mismo que el primer anatemizador titular de los afrancesados, Menéndez y Pelayo, no tiene reparo en silenciar el afrancesamiento de Martínez Marina ${ }^{18}$. O Carlos Seco Serrano se esfuerza en demostrar que Martín Fernández de Navarrete, que fue director de los Reales Estudios de San Isidro bajo José I, «simplemente se inhibe de la lucha, se reduce a ser un "ciudadano pacífico"»" lo encubre: «Utilizando una terminología de última hora [1954], podríamos decir que Navarrete, sin ser un colaboracionista, está bastante lejos de ser un miembro de la resistencia. Posiblemente porque ve en la contienda, ante todo, lo que tiene de guerra civil ${ }^{20}$. Es más, se ocultan las «bajas» motivaciones — si es que se puede calificar así el instinto de supervivencia- que llevaron a Goya a pintar en 1814 los dos cuadros sobre la insurrección de mayo de 1808, por encargo y con el claro fin de embellecer su imagen como verdadero patriota (y no hablamos de los Desastres de la guerra y sus motivaciones intrínsecas). Gérard Dufour, saliendo en defensa de Moratín, escribe: «De hecho, a no ser por su participación en la Comisión encargada de examinar las obras dramáticas originales o traducidas de que haya de componerse el repertorio, que fue creada por decreto del 31 de diciembre de 1810, y en la que participaron también Juan Meléndez Valdés, Vicente González Arnao, Pedro Estala, José Antonio Conde, Tomás García Suelto y Ramón Moreno, su implicación política durante el reinado del Intruso había sido más bien nula $»^{21}$. Lo curioso es que en un reciente y muy interesante libro (por otras razones), a la vez que se califica a Moratín de cínico y acomodaticio, se habla de la postura «un tanto ambigua» de Goya — ¿ambigua? - y la formula así: «Por su ideología y su amistad con los intelectuales, estaba de parte de José. Pero por la crueldad de

17 A pesar de constituir un magnífico trabajo de investigación sobre los afrancesados, que incluye listas de nombres y puestos ocupados, así como orientaciones y trayectorias, y que incluso promete un Diccionario biográfico de afrancesados, la obra de Juan López Tabar (Los famosos traidores. Los afrancesados durante la crisis del Antiguo Régimen (1808-1833), Madrid, Biblioteca Nueva, 2001), no menciona a Goya excepto en una nota al final del libro.

18 JuretschKe, Los afrancesados, pág. 268.

19 Carlos Seco Serrano, «Introducción», en Martín Fernández de Navarrete, Obras, Madrid, Atlas (BAE 75), 1954, pág. XXIX.

20 SEco SERRANo, «Introducción», pág. XXIX.

${ }^{21}$ Gérard Dufour, «Los afrancesados o una cuestión política: los límites del despotismo ilustrado», en Cambio social y ficción literaria en la España de Moratín, coord. de Teresa Nava Rodríguez, Anejo VI, Cuadernos de Historia Moderna (2007), pág. 270 
la guerra, estaba con el pueblo» ${ }^{22}$ ¿ ¿Quiere eso decir que los demás ilustrados —insensibles y obscenamente perversos- no «estaban con el pueblo» sino que disfrutaban con su sufrimiento? ¿Y con qué pueblo estaba Goya? ¿Y contra qué pueblo estaban «los demás» afrancesados? Eso me hace pensar en una película franquista como la Agustina de Aragón de Juan de Orduña, donde los afrancesados son malos y crueles hasta que descubren que la bondad está del lado de... Fernando VII. Guillermo Carnero ha atribuido esa marginación de los afrancesados al hecho de que todas las corrientes antifernandinas coinciden en «el pacto con la monarquía borbónica» ${ }^{23}$, de ahí «la marginación unánime de los afrancesados, sin futuro político aun cuando tolerados, por haber admitido la conservación de la monarquía como institución al margen de la fidelidad dinástica» ${ }^{24}$. En pocas palabras, lo cierto es que las huellas que toda esa trayectoria ha dejado en el imaginario colectivo nacional — de derechas o de izquierdas- parece difícilmente modificable.

Un espacio particular entre los afrancesados, como hemos sugerido al principio, lo ocupa sin duda Goya, porque siendo como fue un ilustrado, del círculo de Godoy, pintor de cámara con Carlos IV y Fernando VII, así como bajo José I - y por tanto afrancesado sin la menor excusa, ni falta que hace-, acusado por la Inquisición tras el retorno de Fernando VII, exiliado al final de su larga vida, también él está asociado a la vida de Cervantes y del Quijote. Y no se trata de una asociación cualquiera. En las imágenes de don Quijote podríamos sintetizar la trayectoria de Goya (al menos como grabador y dibujante).

La primera aproximación de Goya al Quijote — al menos, de la que haya quedado huella visible - tiene que ver con la preparación de la mal llamada edición de 1780 auspiciada por la Real Academia Española con el apoyo abierto y directo del gobierno de Grimaldi ${ }^{25}$. Así, el 25 de mayo de 1773 consta en el Libro 13 de acuerdos de la Academia ${ }^{26}$ que de los 66 sucesos propuestos para ser tema de las ilustraciones, el triunvirato de sujetos encargados — «una diputación de tres sujetos», según el libro de la Academia, compuesta por Manuel de Lardizábal, Vicente de los Ríos e Ignacio Hermosilla— elige 33; el 15 de junio se decide ir adelante con esos 33 episodios,

22 Manuel Moreno Alonso, José Bonaparte. Un rey republicano en el trono de España, Madrid, La Esfera de los Libros, 2008, pág. 245.

23 Guillermo Carnero, Los orígenes del romanticismo reaccionario español. El matrimonio Böhl de Faber, Valencia, Universidad de Valencia, 1978, pág. 165.

24 G. Carnero, Los orígenes, pág. 165.

25 Véase De la palabra a la imagen. El «Quijote» de la Academia de 1780, ed. de Elena Santiago Páez, Madrid, Biblioteca Nacional, 2006; también Francisco Calvo Serraller, Ilustraciones al Quijote de la Academia, Madrid, Turner, 1978.

26 Archivo de la Real Academia Española. Libros de acuerdos (sin paginación). 
[...] como los más a propósito para esto y que expresan con más viveza y propiedad el carácter de Dn. Quijote y de Sancho Panza; propusimos para grabadores de estas 33 láminas a Dn. Manuel Salvador Carmona, Dn. Jerónimo Gil, Dn. Francisco Montaner y Dn. Joaquín Ballester, dando ocho a cada uno, a excepción de Gil, quien ha de grabar también el frontispicio de la impresión; para los dibujos propusimos a Fernando Selma por ser el mejor y por estar desocupado, dándole los asuntos por escrito con toda individualidad, estudiados en la misma obra.

A esas decisiones se añade «que los retratos de Dn. Quijote, de Sancho y de las demás figuras se han de sacar igualmente de las pinturas que hace Cervantes; y que los trajes se arreglen en todo a los que se usaron en los siglos 15 y 16», dice el secretario de la Academia. Nótese el interés de los académicos por elegir a los mejores dibujantes, pero también su preocupación por una representación lo más ajustada posible a las costumbres de la época de Cervantes. Como subrayan Blas y Matilla, la Academia «redactó unas precisas instrucciones que sirvieron de guía a los artistas para la elaboración de sus dibujos» ${ }^{27}$, pero también esa "guía», las instrucciones, «evidencian la escasa libertad que se les concedió a la hora de concebir su obra y el férreo control que la Academia ejerció» ${ }^{28}$. La asociación con la Real Academia de Bellas Artes de San Fernando quedó claramente establecida al decidir la Española que las estampas fueran dibujadas «por los mejores profesores de la Academia de San Fernando». No hay rastro sobre quién ni por qué pensó en Goya o por qué se le asignó el tema específico que presentó, aunque la influencia de Bayeu, su cuñado ya bien instalado en Madrid y los ambientes académicos, no debió de ser ajena. Curiosamente, acabaría no aceptándose —aunque sí pagándosele los 900 reales - la lámina propuesta por Goya, que compuso el dibujo que ilustraba la Aventura del rebuzno; el dibujante y pintor aragonés años después —creemos que en el ámbito creativo y técnico del conjunto de los Disparates - realizará un grabado con una imagen del hidalgo manchego leyendo libros de caballerías y sugiriendo que aparecen delirios en su mente. Pero vayamos por partes.

Como se sabe, y resume Lucía Megías en el blog del IV Centenario del Quijote:

27 Javier Blas y José Manuel Matilla, «Imprenta e ideología: el Quijote de la Academia, 1773-1780», en Imágenes del Quijote. Modelos de representación en las ediciones de los siglos XVII a XIX, Madrid, The Hispanic Society of America, Museo Nacional del Prado, Real Academia de Bellas Artes de San Fernando, 2003, pág. 80.

28 Blas y Matilla, «Imprenta e ideología», pág. 80. 
A Goya le tocó ilustrar el episodio de la Aventura del rebuzno. Junto con el encargo le hicieron llegar una hoja con las instrucciones precisas para su representación: «Se figurará en un campo un escuadrón de gentes, unos a pie y algunos a caballo...», que Goya siguió al pie de la letra; no era cuestión que cometiera un error en la siempre resbaladiza Corte madrileña. Entregó puntualmente su dibujo, cobró, como el resto de los pintores, 900 reales, y a los pocos meses Fabregat grabó su dibujo en una espléndida estampa. Sin embargo, por razones que nadie ha explicado — y que Goya probablemente no pudo ni imaginar y aún menos aceptar sin algún exabrupto - esa imagen, esa estampa, no fue incluida en la edición de la Real Academia Española. Es cierto que Goya siguió «más o menos» al pie de la letra las instrucciones, lo cual da como resultado una lámina bien hecha, clara, sobre un asunto que no plantea mayores dudas ni problemas. La organización de su material ha sido descrita así por Schmidt: una pirámide estable, formada por las figuras de don Quijote, montado y enfadado, a la izquierda; el campesino a pie que golpea con un palo a Sancho y lo descabalga del Rucio a la derecha, y los aldeanos del pueblo del Rebuzno montados y enmarcados por el estandarte del pueblo ${ }^{29}$.

Sin contar con el dibujo de Goya, nuestra visión de la imagen pasa obligadamente por la ejecución que José Joaquín Fabregat hizo como grabador. Como recordaba Escandell Proust, la estampa grabada se entregó a la Real Academia Española el 11 de abril de $1778^{30}$. Ahí se ve a don Quijote sobre Rocinante con su lanza y su adarga, situado a la izquierda del espacio, acosando a un grupo de aldeanos entre los que destaca, al margen derecho del primer plano, un asno del que parece estar cayendo Sancho Panza, golpeado por un aldeano rival. Al fondo se vislumbra un par de caballos y un estandarte que muestra la imagen de otro asno. Tras ellos se vislumbra una columna de villanos, es decir, gente del pueblo del Rebuzno. Schmidt ${ }^{31}$ recuerda que Mengs aconsejaba la composición triangular (o piramidal) para crear una formación de figuras establecida con solidez.

Escandell Proust llama la atención, como virtudes de la estampa goyesca, sobre «la monumentalidad y volumen de las figuras, que crean espacio a su alre-

29 José Manuel Lucía Megías, «Francisco de Goya y el Quijote», Disponible en <http://ivcentenarioquijote.blogspot.ca/2005/06/francisco-de-goya-y-el-quijote-ii.html>; Rachel SchmidT, The Canonization of «Don Quixote» through Illustrated Editions of the Eighteenth Century, Montreal, McGill-Queen's University Press, 1999, pág. 175.

30 Isabel Escandell Proust, «Goya, autor de dos imágenes de don Quijote», en Volver a Cervantes: actas del IV Congreso Internacional de la Asociación de Cervantistas, coord. Antonio Pablo Bernat Vistarini, Palma de Mallorca, Universitat de les Illes Balears, 2001, t. I, pág. 417.

31 Sснмid, The Canonization, pág. 175. 


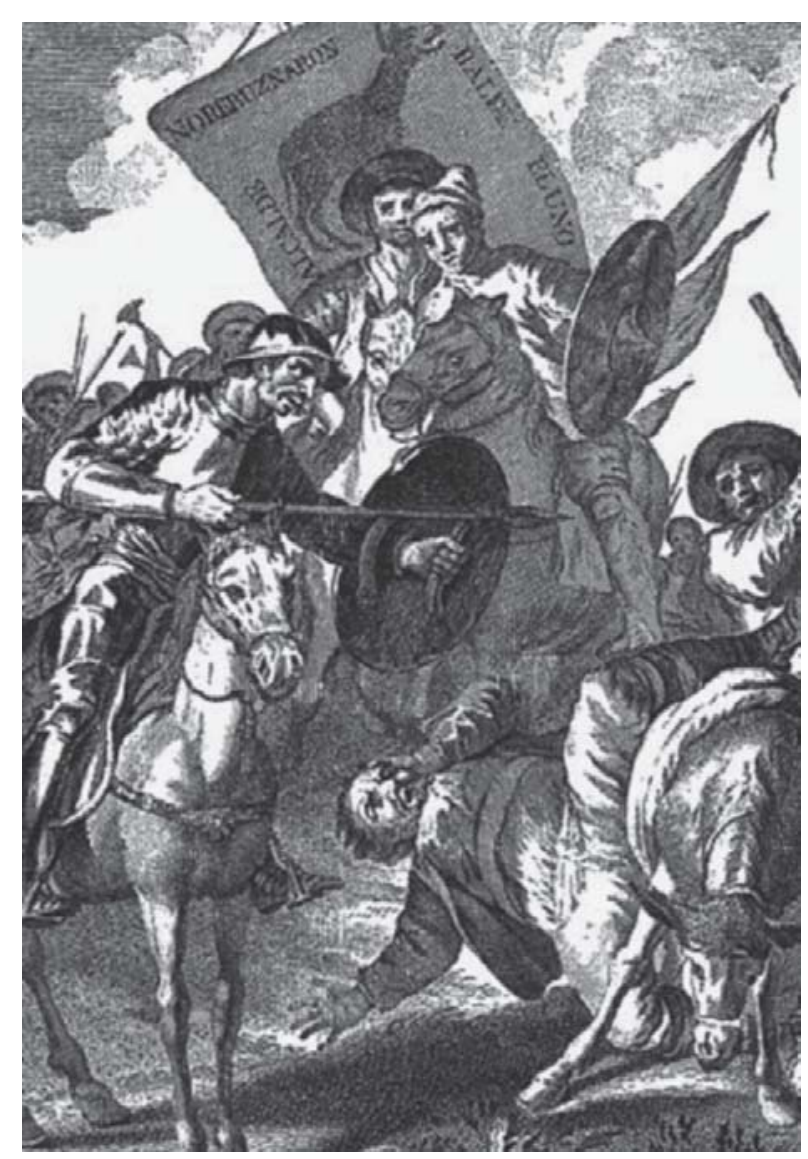

Aventura del rebuzno, entregada a la Real Academia Española el 11 de abril de 1778 y grabada por Fabregat

dedor, así como la profundidad destacada por la pirámide compositiva ${ }^{32}$. Pese a la bondad y calidad del dibujo y de la impresión, nada particular sobresale en él. Obra bien cumplida, encargo realizado a lo que podríamos considerar satisfacción del cliente. Preguntarse por las razones del posible interés de Goya por ese asunto es salir por peteneras, porque en ese momento de su estancia en Madrid es difícil suponer que tenía intereses específicos respecto a la ilustración del Quijote. Pero Escandell Proust resumió las supuestas razones esgrimidas para explicar por qué la estampa goyesca fue descartada: «Se ha supuesto que la razón debía ser que esta estampa no se adecuaba al gusto de los académicos, tal vez por su falta de academicismo o por carecer de la recreación histórica fidedigna que exigían ${ }^{33}$, pero ella misma rechaza esa hipótesis, dedicando un espacio notable a la cuestión del academicismo para concluir que el dibujo de

32 Escandell Proust, «Goya, autor», pág. 421.

33 Escandell Proust, «Goya, autor», pág. 420. 
Goya siguió fielmente el texto literario y no incluyó nada que pudiera tomarse por «anti-academicismo». A Goya se le encargó este asunto y él obedeció a su cliente, que en este caso era ni más ni menos que la Real Academia. Nada más. Como afirman Blas y Matilla, «el Goya de la década de 1770 era un artista tan sumiso y respetuoso de las imposiciones como cualquiera de sus compañeros» ${ }^{34}$. Y tienen razón, porque el mito de un Goya rebelde, enfrentado a instituciones y autoridades, no es más que eso, un mito. El estudio de Soubeyroux para demostrar una coherencia ideológica a favor de una Constitución democrática antes de su propia existencia es admirable y sugerente ${ }^{35}$, pero más que poco convincente, sobre todo cuando uno tiene que afrontar los dibujos o pinturas por encargo. Ello no quiere decir que en su intimidad Goya no mantuviera opiniones que podían aproximarse a un liberalismo radical o a un democratismo contundente, como ya sugirió hace años F. D. Klingender ${ }^{36}$. Escandell Proust propone como el auténtico motivo del descarte el que «en ningún caso un solo capítulo se ilustra con dos imágenes ${ }^{37}$ y recuerda que en el mismo capítulo de la Aventura del rebuzno se encuentra el episodio del retablo de maese Pedro, que fue el finalmente elegido para ilustrar el capítulo; por lo tanto, la explicación acaba siendo bastante simple: esa fue la decisión de los responsables de la Academia, que optaron por no dedicar dos estampas a un solo capítulo, pues la del retablo sí la tuvo. En modo alguno puede afirmarse - y demostrar - que el pintor pretendía satirizar la locura de los aldeanos implicados en la rivalidad a causa del rebuzno. Claro que la situación es ridícula, pero esa era la óptica de Cervantes y así la presenta, no la de Goya, que es un mandado.

Schmidt ${ }^{38}$, como otras personas, ha especulado también sobre las razones que pudieron justificar la exclusión de la estampa de Goya de la famosa edición. Supone que tal vez fue por el uso de un contenido carnavalesco, demasiado atrevido para la estética neoclásica conservadora; o tal vez que los personajes fueran presentados como víctimas de la locura de otros y no de ellos mismos, base de la voz del pueblo sobre don Quijote, que este era el loco y los demás los cuerdos. Martínez Ibáñez recordó que para Lafuente Ferrari la explicación «debió ser por no haberse ajustado a las normas dadas por la Real Academia de la Lengua», pero, puesto que otros dibujantes — como Carnicero- tampoco se ajustaron, deduce esta historiadora que la única razón fue que el dibujo de

34 Blas y Matilla, «Imprenta e ideología», pág. 84.

35 Jacques Soubeyroux, Goya politique, Cabris, Sulliver, 2011.

36 F. D. Kuingender, Goya in the democratic tradition, introd. by Herbert Read, New York, Schocken Books, [1968].

37 Escandell Proust, «Goya, autor», pág. 421.

38 SснмiDT, The Canonization, pág. 177. 
Goya rompía «con el academicismo imperante» ${ }^{39}$. Cuesta García, años después, volvió a acercarse a las causas del descarte de «la estampa goyesca», comparándola específicamente a la de Carnicero — más en concreto, a la estampa del frontispicio de la obra, grabada por F. Selma - pero el problema es que no se refiere a la estampa que Goya propuso para la Aventura del rebuzno y la edición académica del Quijote, sino la que se conserva en el British Museum, es decir, un dibujo que no se concibió para figurar en ninguna edición del Quijote y que con toda seguridad se hizo mucho más tarde, pero volveremos a ello ${ }^{40}$. La realidad, sin embargo y como ya hemos sugerido apoyándonos en Escandell Proust, puede resultar bastante más prosaica. Si se lee con detenimiento lo que esperaba la Academia, es decir, sus instrucciones para la composición de la estampa, comprobamos que Goya se ha saltado bastantes de ellas; en concreto, los aldeanos deberían ir armados «con lanzas, ballestas, arcabuces, alabardas, picas y rodelas, uno tendrá un tambor y otro una trompeta», pero Goya ha mostrado solo algunas lanzas y una trompeta; la Academia exigía: «se dejarán ver dos o tres estandartes» y Goya pintó solo uno, el más significativo sin duda;

Sancho, decía la Academia, estará sobre el Rucio [...] tendrá las manos puestas en las narices y la boca abierta en acción de rebuznar y tras él estará uno de los del escuadrón a caballo dándole un fuerte palo por las espaldas. La acción de Sancho será mantenerse con la boca abierta, la una mano puesta en las narices, la otra en el aire, y el cuerpo ladeado como que va a caer del Rucio, al modo de un hombre que estando haciendo alguna cosa le cogen descuidado y repentinamente le dan un golpe tan fuerte que le obliga a caer en el suelo con tanta prontitud y violencia que se conserva al caer casi la misma postura y acción que tenía al tiempo de recibir el golpe ${ }^{41}$.

Aceptemos que entender y dar forma a lo que pedía la Academia era poco menos que imposible, pero lo último que nos sugiere la estampa es que Sancho está rebuznando. Cayéndose, parece echarse la mano izquierda a la cara, y el aldeano que lo golpea no va a caballo. Por último, «los que están junto a D. Quijote estarán en ademán de encararle las lanzas, arcabuces y otros le estarán

39 Las dos citas en María Antonia Martínez IbáñEz, «Un dibujo de Goya para El Quijote de Ibarra que no fue aceptado», Archivo Español de Arte, 250 (1990), pág. 312.

40 María José Cuesta García de Leonardo, «Don Quijote en dos versiones dieciochescas: Carnicero y Goya», Ensayos: Revista de la Facultad de Educación de Albacete, 20 (2005), págs. 19-32. Esa datación, creemos que errónea, es también la que sigue Emmanuel Morigno: Emmanuel Marigno, «La visión de don Quijote, de Francisco Goya: un autoportrait métaphorique?», Crisoladas, 1 (Octobre 2006), págs. 163-164.

$41 \quad$ En De la palabra a la imagen, pág. 378. 
tirando pedradas, de suerte que se vean algunas piedras cerca de D. Quijote»: nada de eso ha sido recogido por Goya. A este no le faltaban razones estéticas y técnicas para simplificar la composición, pues lo que pretendía la Academia hubiera producido un mazacote infumable sin visibilidad alguna de la aventura representada, aunque eso no le otorga a su dibujo ninguna excepcionalidad original o ningún enfoque impredecible. Otros dibujantes, como varios críticos han señalado, también se saltaron algunas instrucciones ${ }^{42}$, pero probablemente no tantas como Goya. Y ahí se encuentra probablemente la explicación de su ausencia o mejor de por qué su estampa no superó la del retablo de maese Pedro: la desobediencia flagrante de algunas de las instrucciones académicas. Insistamos, además, en que la posición en las instituciones del Goya de 1778 no es la misma que la que tendrá más adelante. Goya se había trasladado a Madrid en 1775 y sus encargos más notables en los siguientes años fueron los cartones para tapices que logró gracias a la influencia de su cuñado Francisco Bayeu. Está lejos todavía su nombramiento como académico de mérito —en 1780_, la protección del infante Luis de Borbón, o su puesto como pintor de cámara —en 1789—, su proximidad al círculo de los duques de Osuna y un etcétera que no son sino penosos escalones que le llevarán a ser el primer pintor de cámara en 1799.

En esos años Goya vive cambios notables que sin duda afectarán su pintura, porque la situación, aun contando con la protección de Godoy, ha cambiado y sigue cambiando. Habiendo sido acogido en la Real Academia de Bellas Artes de San Fernando, el 14 de octubre de 1792 presenta su memoria sobre el método de enseñanza que debe aplicar la institución. Algunos autores, de modo paralelo a como Menéndez Pelayo interpretó unas palabras sueltas de Feijoo para hablar de una estética nada neoclásica —nada «francesa»— y mucho «romántica», ha leído lo que dijo Goya como una declaración de principios antineoclásicos y a favor de la libertad del genio, casi al modo romántico. Sin embargo, en esa memoria Goya reafirma uno de los principios clave del neoclasicismo, es decir, el principio de «la imitación de la divina naturaleza» ${ }^{43}$ o el de «imitación de la verdad»; es más, aunque habla contra los «preceptos mecánicos, premios mensuales, ayudas de costa y otras pequeñeces que envilecen y afeminan un arte tan liberal y noble como es la pintura», defiende la idea de «dar pocas reglas de las profundas funciones del entendimiento que para esto [la pintura] se necesitan» y propone como método para adelantar las artes «el de premiar y proteger al que

42 Blas y Matilla, «Imprenta e ideología», págs. 80-81.

43 Las citas provienen del texto de la memoria, en Janis A. Tombinson, Goya in the Twilight of Enlightenment. New Haven \& London, Yale University Press, 1992, págs. 191-192. 
despunte en ellas; el de dar mucha estimación al profesor que lo sea; y el de dejar en su plena libertad correr el genio de los discípulos que quieren aprenderlas». Entiéndase, pues, que su defensa de la libertad está, digamos, circunscrita por el principio neoclásico de imitar la verdad de la naturaleza. Pero su arte está evolucionando a todos los niveles. El documento más significativo en este sentido es la impresión y venta (frustrada) de los Caprichos y la dedicación a los grabados y sus diferentes técnicas, con las correspondientes series por venir.

Así, pues, en comparación con la estampa para la edición académica, algo muy distinto sucede con la otra aproximación de Goya a Don Quijote; me refiero a su «disparate» del Quijote leyendo, que no lleva ningún título autógrafo ${ }^{44}$ (conocido bajo nombres tan diversos como «Visión de don Quijote», «Don Quijote y sus monstruos», «Don Quijote leyendo libros de caballerías»), cuya historia es ya propia de una novela de investigación, y nos atrevemos a calificarlo de disparate y no de capricho, porque este dibujo es de la época de los Disparates, sin la menor duda. Escandell Proust afirma que el dibujo «tiene ciertas similitudes con la serie de estampas los Caprichos que es necesario matizar ${ }^{45}$, y eso es lo que ella hace. Cuesta García, cuyo trabajo inicialmente se proponía comparar a Carnicero con Goya — confundiendo la datación del dibujo que vemos al ubicarlo hacia 1780 - acaba más bien comparando el capricho 43, «El sueño de la razón produce monstruos» y el dibujo sobre don Quijote. Sin embargo, creemos que por la composición, por la técnica y por ciertos detalles en la construcción de las figuras, se vincula mucho más acentuadamente con los Disparates que con los Caprichos, aunque varias de las series goyescas se solapan y acaba siendo muy problemática una diferenciación entre ellas. En particular cuando además no hablamos de series grabadas sino de los famosos e incomparables álbumes de dibujos, o sea, los «diarios» en imágenes que llevaba Goya. No obstante, recuperemos la definición que proporciona Autoridades del capricho: «Dictamen formado de idea, y por lo general fuera de las reglas ordinarias y comunes. En la pintura vale lo mismo que concepto». Pero también encontramos esto: «Hombre de capricho. Se llama el que tiene agudeza para formar ideas singulares, y con novedad, que tengan feliz éxito». Por su parte, Estaban de Terreros incluye este par de entradas: «Extravagancia, conducta de un hombre que en vez de seguir la razón se deja llevar de la fantasía u obstinación»; pero también «se dice en la música, poesía, \&c. de aquello que da gusto más por razón de su extravagancia o modo extraordinario de pensar y componer que por la observancia exacta de las reglas».

44 A pesar de lo que afirma Marigno en «La visión de don Quijote», pág. 162.

45 Escandell Proust, «Goya, autor», pág. 416. 


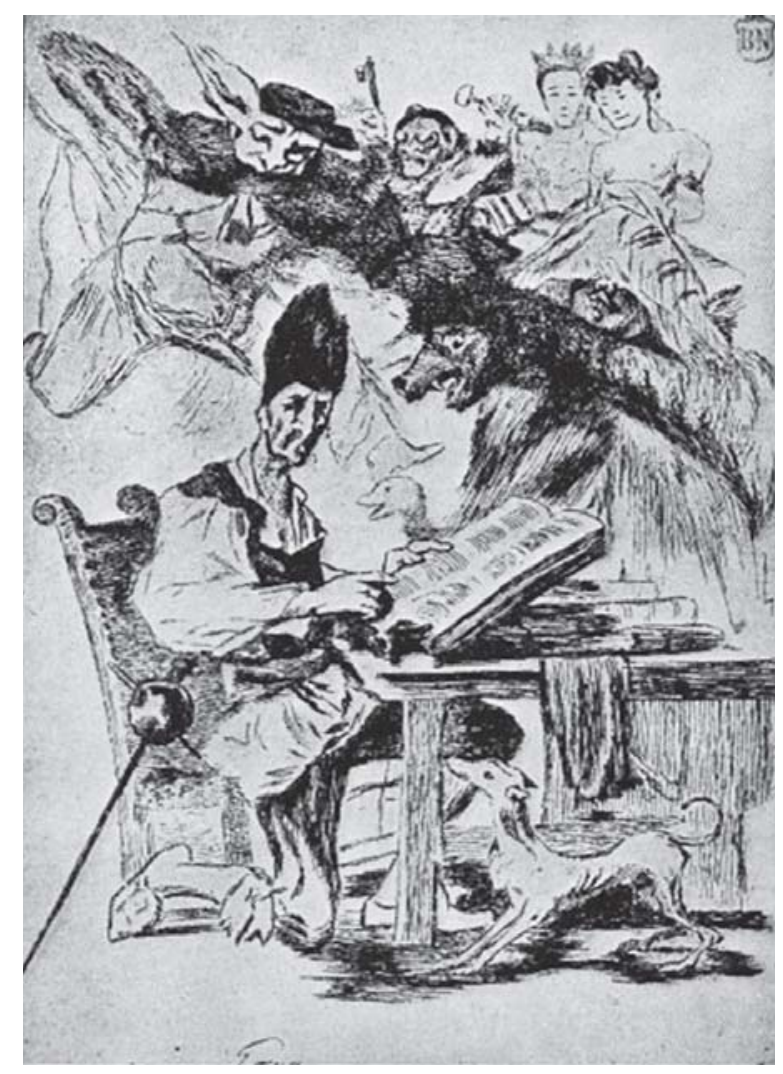

Dibujo del álbum F (1813-1823) grabada por Bracquemod, que se encuentra en la Biblioteca Nacional

Y veamos lo que dice sobre el disparate: «Hecho o dicho fuera de propósito y de razón. Díjose Disparate de Dispar, por no tener paridad, ni conformidad con la razón». Pero Terreros dice bajo disparatar: «desatinar, delirar», pero disparate es «empresa o acción imprudente». Hay, por lo tanto, parentescos evidentes entre capricho y disparate, pero la figura misma de don Quijote nos parece cuadrar más adecuadamente en el conjunto de los Disparates ${ }^{46}$. La posible datación del dibujo también apunta en esa dirección, pues para entonces Goya había cerrado la serie de Caprichos, a pesar del título que da a la tercera parte de las Fatales consecuencias, es decir, Caprichos enfáticos. Fue Pierre Gassier quien reconoció el papel como perteneciente al álbum sepia de Goya, también llamado Imágenes de España y conocido como álbum F, realizado entre 1813 y $1823^{47}$, pero también razones de técnica y estilo le reforzaron en esas

46 Véase Priscilla Muller, «Pensamientos sobre los Disparates de Goya», en Goya. Nuevas visiones. Homenaje a Enrique Lafuente Ferrari, ed. de Isabel García de la Rasilla y Francisco Calvo Serraller, Madrid, Amigos del Museo del Prado, 1987, págs. 291-305.

47 Pierre Gassier, The Drawings of Goya. The Complete Albums, London, Thames and Hudson, 1973, pág. 486. 
fechas. Wilson-Bareau recuerda que Carderera sugería que el álbum F habría sido compuesto en Madrid hacia $1819^{48}$. Escandell Proust se acoge al contexto - y a una aceptación acrítica de la sugerencia de Gallardo sobre el presunto proyecto goyesco de Visiones de don Quijote, idea muy poco documentada y que otros cervantistas han acogido sin parpadear- para suponer que este dibujo se sitúa como en continuación a los Caprichos, entre 1799 y 1808. Pero olvida que no hay contradicción entre los Desastres y los caprichos enfáticos. Atribuir «un mismo espíritu y contexto ideológico ${ }^{49}$ a los Caprichos y a este dibujo exigiría argumentos más convincentes. Podríamos sugerir que los Disparates hubieran podido llamarse Caprichos disparatados, pero nos parece alejarse demasiado de la intención goyesca. En cualquier caso, la influencia del contexto - la ocupación del trono por Fernando VII- no tendría ninguna significación si pensamos en el álbum como un documento absolutamente privado y no como algo concebido para mostrarse a la mirada pública.

Un breve excurso para comentar las «visiones» de Gallardo. En su artículo escribe, refiriéndose a sí mismo y en particular a su proyecto de llevar a cabo una edición del Quijote con ilustraciones:

Tenía estudiados nuevos asuntos para las láminas del Quijote, que, consultados con el gran Goya, habían merecido su aprobación. Goya era un pintor filósofo: acuérdome bien de que, contestándome sobre este punto a Londres por mano de un caballero inglés que hoy reside en Sevilla, me decía que en tiempos había él fantaseado unos caprichos originales con el título de Visiones de don Quijote, en que, por nuevo estilo, pintaba las fantasías del lunático Caballero de la Mancha. Solo el pensamiento este de Goya es ya una creación artística, propia de su travesura $^{50}$.

La única referencia existente a esas Visiones de don Quijote ha salido de la mente de un potencial editor de la obra cervantina que pretende enriquecer con láminas novedosas y para cuya legitimidad no encuentra mejor respaldo que la presunta aprobación de un Goya que evidentemente no puede atestiguar nada.

48 Juliet Wilson-Bareau, Goya’s Prints. The Thomas Harris Collection in the British Museum, London, The Trustees of the British Museum, 1981, pág. 85.

49 Escandell Proust, «Goya, autor», pág. 426.

50 Bartolomé José Gallardo, «La Tía fingida, ¿es novela de Cervantes?», El Criticón 1 (1832), pág. 41. No creo que se pueda convertir en un hecho indiscutible la existencia de ese proyecto, ni afirmar que esas opiniones de Gallardo se encuentran efectivamente en una carta que solo él menciona (véase SCHMIDT, «Nuevas aportaciones al estudio de la iconografía cervantina en la obra de Goya», Volver a Cervantes: actas del IV Congreso Internacional de la Asociación de Cervantistas, coord. Antonio Pablo Bernat Vistarini, Palma de Mallorca, Universitat de les Illes Balears, 2001, t. I, pág. 440). 
Dar por supuesto que esas visiones constituyeron un proyecto real de Goya es entrar en una fantasía propia del pintor y del autor del Quijote, sin duda.

Hay que señalar que hemos contemplado dos encarnaciones de la imagen, una, la del aguafuerte realizado por Felix Bracquemond y publicado por Valentín Carderera ${ }^{51}$ en la Gazette des Beaux-Arts, en 1860, entre las páginas 224 y 225, a partir del dibujo original que conserva el British Museum; y dos, el dibujo original en el que Goya anotó el número 54 y que lleva su nombre autógrafo. La mayor diferencia que contemplamos entre las dos es la intensidad que otorga al dibujo el pasarlo por la tinta, por lo que el grabado resulta mucho más oscuro que el dibujo del álbum; asimismo, Bracquemond ha realzado la imagen del pato y ha hecho desaparecer el escudo al margen de la espada. Escribe a propósito de ese dibujo en el mismo blog citado antes Lucía Megías:

El British Museum de Londres conserva un dibujo original de Goya, que se data entre 1817 y 1820. Allí aparece Alonso Quijano como lector de libros de caballerías; sentado en una pobre mesa, con su espada presta para ser blandida; bajo la atenta mirada de su galgo corredor, el hidalgo manchego parece hacer un alto en su lectura, y señalando una línea de su libro de caballerías, casi nos mira a los ojos mientras en sus labios cerrados permanece la frase: «La razón de la sinrazón que a mi razón se hace, de tal manera mi razón enflaquece, que con razón me quejo de la vuestra fermosura». Una verdadera oración.

Sobre su cabeza, sobre su imaginación se agolpan los recuerdos de personajes y de aventuras que le convertirán en un personaje de ficción dentro de un libro de caballerías de entretenimiento (cuando en realidad no es más que un personaje de ficción en el mejor libro de caballerías de todos los tiempos, el Quijote). Y allí las princesas ceden el protagonismo a los encantadores y demás monstruos que pueblan la imaginación de nuestro personaje. Primer y último dibujo de una nueva serie de grabados: «Visiones del Quijote» que, a imagen y semejanza de sus caprichos, había ideado Goya al final de su vida.

La Biblioteca Municipal Cardenal Cisneros conserva una litografía, realizada por Braquemont [por Bracquemond] a partir de este dibujo, y que fue publicada en la parisina Gazette des Beaux-Arts, en 1860, acompañando a un artículo de D. Valentín Calderera [por Carderera].

Según Wilson-Bareau, la imagen que comentamos tiene la apariencia de «a design for a title-page and recalls Goya's original frontispiece for his Sueños,

51 Valentín Carderera, «François Goya, sa vie, ses dessins et ses eaux-fortes», Gazette des Beaux-Arts, VII (1860), págs. 215-227. Disponible en <http://gallica.bnf.fr/ark:/12148/bpt6k2030710/f231.image.r=>. 
etched as plate 43 of the Caprichos» ${ }^{52}$, es decir, el capricho «El sueño de la razón produce monstruos», parentesco que desarrollaría más tarde, como ya indicamos, Cuesta García. La misma Wilson-Bareau recuerda que en 1819 Goya estaba inmerso en los Disparates, y que otro dibujo del mismo álbum sirvió para otro grabado en ese año. Asimismo, Wilson-Bareau menciona que hay una serie de dibujos en el álbum F - del 10 al 15-que representan a hombres vestidos de época, en duelo con espadas. Más adelante, rodeando el dibujo que nos ocupa, se encuentra un apuñalamiento (el número 53), y una mujer hablando con un viejo en lo que parece una iglesia (el número 55). ¿Nos dice algo sobre el papel que don Quijote desempeña en la psicología del pintor? Digamos que confirma el hecho de que un diario de notas en imágenes no tiene a priori lógica alguna. De aceptar el proyecto Visiones del Quijote parece esperable ver algún otro apunte en ese álbum, pero no es así. Nos encontramos, en efecto, ante un dibujo a pincel en tinta gris-sepia y aguada. Y, para retomar nuestra propuesta de calificarlo de disparate, podemos decir que nadie como don Quijote podría encarnar mejor la idea misma del disparate, pues el cura habla de los «concertados disparates» (I, 50) del héroe cervantino. Pero, a diferencia de la estampa para la edición académica, aquí todo es nuevo, todo es Goya, todo es sugerente y mágico, encantador y desasosegante.

La composición tiene tres componentes: uno piramidal, ocupado por el cuerpo de don Quijote — vértices en el pelo, la punta de la espada y la cabeza del perro-, otro paralelo al suelo y compuesto por la mesa y el puño de la espada, y aún otro en friso oblicuo que desciende hacia la derecha del espacio, siguiendo lo que podría ser una gruesa rama - Cuesta García lo interpreta como las alas abiertas del oso, pero volveremos- y sobre la que se sitúan las figuras «imaginarias» o imaginadas por don Quijote. El centro de la imagen, algo desplazado a la izquierda, lo ocupa don Quijote sentado sobre una silla estilo castellano, las piernas en posición algo forzada, con una de ellas apoyando la rodilla en el suelo, la espada como si se sostuviera sobre el lateral delantero de la silla, pero, como bien señaló Schmidt ${ }^{53}$, no hay ningún punto de contacto entre el puño de la espada y la silla, aunque no vemos —en el aguafuerte- el borde de ningún escudo en ningún lugar (como sugería Schmidt), escudo que sí aparece en el dibujo original que conserva el British Museum. Cuesta García describe así su apariencia: «un vestido desaliñado, con camisa, coleto, calzas, medias y estilizados borceguíes $»^{54}$. También es cierto

52 Wilson-Bareau, Goya’s Prints, pág. 85.

53 Sснмid, The Canonization, pág. 178.

54 Cuesta García, «Don Quijote», pág. 25. 
que no se ve el apoyabrazos donde se supone que don Quijote está apoyando el suyo. Tal vez sea cierto que «The laws of rationally illusionistic pictorial depiction are suspended, even as they appear to be mimicked $»^{55}$, como dice Schmidt, pero estamos seguros de que es un apunte, un dibujo anotado en un álbum o cuaderno de apuntes, por lo que Goya pudo dejarlo como inacabado. La mesa parece baja y sobre ella varios in-folios sirven de apoyo al que tiene abierto el personaje, en el que un dedo apunta a un párrafo preciso, a una línea concreta, tal vez la que, con un poco de imaginación, Lucía Megías apuntaba en su blog. Pero tal vez otra, no de ningún libro de caballerías, sino del Prólogo que escribiría Cervantes o, más bien, de su propia historia, en este caso ahí al comienzo del capítulo 30 de la Segunda parte, donde aparecen los duques... Cosa imposible por el formato del volumen.

Un podenco bastante famélico — el galgo corredor decía Lucía Megíasocupa el centro delantero de la escena, casi situado bajo la mesa, en tanto que detrás de la misma, un poco en alto, se vislumbra un pato u oca. Sin embargo, no es el perro el que atrae la mirada, que se va en primera instancia al hombre que lee, vestido de casa, con un pelo extraño de textura semejante a la de otras figuras de los disparates, quizás como si una descarga eléctrica se lo hubiera levantado todo él, o como si llevara un gorro de estar por casa. Sus manos se dividen entre la que sostiene el gran folio y la que señala un párrafo del texto. Su mirada, intensa y profunda, se dirige — muy goyescamente — a quien lo contem$\mathrm{pla}^{56}$. Y en esa mirada podemos intuir la diferencia que separa este dibujo del capricho $43^{57}$, porque, sintetizando, allí un hombre duerme recostado sobre un escritorio y detrás de su cabeza se erige la pirámide de animales nocturnos; aquí, un hombre bien despierto y sentado mira al espectador y por encima aparecen en friso personajes muy reales del libro que está leyendo y que, no por casualidad, es la historia de sus propias aventuras (y desventuras). Y el nivel de disparate -capricho o visión - se manifiesta aparente y tal vez superficialmente en el conjunto de figuras que ocupan la parte superior de la estampa, todas ellas al parecer volando o apoyadas en la especie de rama que ya hemos indicado. Esas figuras se dividen entre la que es claramente amenazadora - la cabeza de un jabalí, que muestra sus dientes feroces, y cuya presencia en la montería de los

55 Schmid, The Canonization, pág. 178.

56 Schmidt, «Nuevas aportaciones», t. I, pág. 441, llama la atención sobre esta mirada, pues «es la primera vez en la iconografía del Quijote que el protagonista delirante traspasa el espacio del plano pictórico para dirigirse directamente al ojo de su espectador».

57 Véase, entre la muchísima bibliografía sobre este capricho, John Dowling, «The Crisis of Spanish Enlightenment: Capricho 43 and Goya's Second Portrait of Jovellanos», Eighteenth-Century Studies, 18, $\mathrm{n}^{\circ} 3$ (1985), págs. 331-359. 
duques vio con agudeza Escandell Proust ${ }^{58}$ _, dos mujeres, una con una corona y otra al parecer con los pechos al aire, tal vez la duquesa y una de sus damas, que podría ser Altisidora, cuyo erotismo ha sido puesto de relieve ${ }^{59}$ - , un rostro oscuro que se sitúa entre el jabalí y las faldas de la joven, tal vez mirando por debajo de sus ropas en un toque obsceno muy propio, y, detrás de la duquesa, un apunte que quisiera ser una cara, pero imposible de concretar; sigue una cara de una vieja con unas llaves bien visibles en las manos, tan expresionista como las de los viejos comiendo, que Escandell Proust identifica como una dueña —Cuesta García señala la presencia de «un pañuelo en la cabeza y toquilla sobre los hombros» ${ }^{60}$ — de las que aparecen en el episodio de los duques —doña Rodríguez de Grijalva se presenta en II, 31- entre otras razones por su gesto fruncido, de mal genio; y una última imagen, casi sobre la cabeza de don Quijote, que no se podría asegurar es humana por la oreja visible que, según Cuesta García, recuerda la de los asnos ${ }^{61}$, pero sí con hábitos religiosos, deformación tal vez goyesca —y por ende anticlerical — del personaje del eclesiástico reprehensor — «un grave eclesiástico destos que gobiernan las casas de los príncipes», II, 31 - que cohabita con los duques; todas ellas, en conjunto aunque de identificación difícil, como dice Schmidt ${ }^{62}$, se caracterizan por la fluidez de sus formas grotescas. En último término, sin embargo, podríamos sugerir, como apuntaba tímidamente Escandell Proust, que don Quijote no está con los seres imaginarios que acreditan y dan fe de su locura — es decir, con magos, nigromantes o figuras salidas de los libros de caballerías-, y por tanto de la ausencia diurna de razón, sino, por el contrario, con los personajes de uno de los episodios más sobresalientes de la Segunda parte de su propia novela. Y podríamos añadir que de los episodios más críticos de la obra, especialmente contra la aristocracia castellana. En otras palabras, se trata de don Quijote leyéndose a sí mismo o mejor su historia, pero la Segunda parte, cosa sobre la que no llegó a escribir Cervantes.

Rachel Schmidt habla de un pene erecto en la figura como de duende de la parte superior izquierda —el eclesiástico— (lo mismo que habla de la nariz

58 Escandell Proust, «Goya, autor», pág. 424. En efecto, en II, 34, se habla de un «desmesurado jabalí, crujiendo dientes y colmillos y arrojando espuma por la boca».

59 Escandell Proust, «Goya, autor», pág. 424, menciona también la posibilidad de que sea Dulcinea, pero esa opción no cuadraría ni con su representación ni con el conjunto. Sobre Altisidora, véase Henry Wells SulLivan, «Altisidora: ¿̨como "regalo del más alto" acelera la cura de don Quijote?», Actas de XI Congreso de la Asociación Internacional de Hispanistas (Irvine-92), coord. Juan Villegas, 1994, vol. II, págs. 74-81; Augustin Redondo, «Fiestas burlescas en el palacio ducal: el episodio de Altisidora», Actas del III Congreso Internacional de la Asociación de Cervantistas, ed. de A. Bernat, Palma, Universitat de les Illes Balears, 1999, págs. 49-62.

60 Cuesta García, «Don Quijote», pág. 26.

61 Cuesta García, «Don Quijote», pág. 25.

${ }^{62}$ Sснмidt, The Canonization, pág. 180. 
fálica de don Quijote y del mismo tipo de nariz en «Rara penitencia»), lo que la hace vincularla a un sátiro semejante al del capricho 56 «Subir y bajar». Y una vez establecido que es un sátiro según la estudiosa, eso le permite añadir una interpretación complementaria de la locura de don Quijote como «sexually motivated as well as literarily rooted ${ }^{63}$. Poniendo en relación este grabado con el capricho «El sueño de la razón produce monstruos», Gassier y Wilson concluyen que «les deux compositions en effet montrent l'auteur assailli par les créatures de ses rêves et de ses visions ${ }^{64}{ }^{\text {}}, \mathrm{y}$ Gassier señala que en esta imagen de don Quijote se subvierte la tradición iconográfica hasta el punto en que la lectura ilustrada converge con la romántica ${ }^{65}$.

Nada que ver esta estampa con la presentada para la edición académica de 1780. Este es el mundo de los caprichos y los disparates, el mundo de la imaginación desbridada que coexiste con la realidad viva de cualquier individuo o sujeto. Convertido en icono gráfico, don Quijote acoge la realidad y la ficción, lo real y lo «ideal», lo cotidiano y lo onírico. Schmidt afirma que la manera de Goya (y del impresor Bracquemond) «echoes the transgression of the boundary between the real and the imagined presented by the fantastic creatures of Don Quixote's imagination» ${ }^{66}$. José Camón Aznar sostiene, por su parte, que «Goya no califica. Consigna en breve síntesis las anormalidades y los demonios que palpitan en la rabia de los hombres y en las insinuaciones de la mujer, eludiendo a veces hasta su simpatía por los sacrificados ${ }^{67}$. Y lo distancia de Hogarth - porque Goya no tiene intenciones morales-y de Gross — porque Goya no aspira a una subversión social—, con lo que Goya se queda como un pintor que muestra cosas sin intención ninguna. Sería probablemente el primer caso de la historia. Y supone, de paso, negarle al pintor aragonés su militancia activa en y por el reformismo ilustrado, en y por el liberalismo constitucionalista de $\mathrm{Cádiz}^{68}$. Lo que no quiere decir que sus propuestas se limitaran a ese activismo, pues la dinámica de su pintura lo llevó mucho más allá de dicho programa y al mismo tiempo la prudencia le hizo limitar su manifestación pública. Para Rachel Schmidt, la postura de Ilie al afirmar que Goya sustituye «cognition through dream in the place of cognition through waking reality, sensorial or otherwise ${ }^{69}$ complica la interpretación de Goya por su posición liminal. Lo

63 Schmid, The Canonization, pág. 180.

64 Pierre Gassier et Juliet Wilson, Vie et ouvre de Francisco Goya. L'Euvre complet illustré: peintures, dessins, gravures, Fribourg, Office du livre, 1970, pág. 376; citado en Sснмidт, The Canonization, pág. 181.

65 Schмid, The Canonization, págs. 180-181.

66 Sсниidt, The Canonization, pág. 178.

67 José Camón Aznar, «Estética de Goya», Revista de Ideas Estéticas, 4, 15-16 (1946), pág. 477.

68 Véase Soubeyroux, Goya, politique, págs. 137-158.

69 Citado en Sснміdт, The Canonization, pág. 175. 
que sucede, en primer término, es que la opinión de Ilie no es más que eso, una opinión a mi modo de ver en absoluto convincente; en segundo lugar, es que la idea de que entre ilustración / neoclasicismo y romanticismo hay ruptura radical es una idea falsa, como algunos críticos e historiadores han $\operatorname{argumentado}^{70}$. El desafío para cualquier crític@ es discernir cómo y dónde se producen las quiebras y brota lo diferente. Por eso, calificar a Goya como «Janus-faced artist» ${ }^{71}$ es no percibir esa dinámica cultural y estética que impide dualidades radicales sobre entidades inmutables. Nos parece, sin embargo, muy sugerente vincular la locura —incluida la de don Quijote- a «los excesos irracionales de la Restauración [de Fernando VII] ${ }^{72}$ », aunque creemos que ver en las figuras que aparecen en este dibujo seres monstruosos producto de una psicología enferma no recoge las identidades de aquellas. Tampoco nos parece convincente el argumento a favor de un autorretrato metafórico ${ }^{73}$ del propio pintor, pues en ningún lugar nos parece que Goya se haya visto a sí mismo como un loco. Y suponer que la figura masculina del capricho 43 es un autorretrato del Goya loco es extender la metáfora muy lejos de lo que nos muestra el grabado.

Si tratáramos de sintetizar las diferencias que se hacen evidentes entre los dos dibujos relacionados con Cervantes y buscáramos una explicación, no creo que se pueda acudir a respuestas del tipo evolución de su estética o modernidad de la última a causa de una libertad pública restaurada. Por el contrario, creo que hay que recurrir a una dualidad que caracteriza, por lo que sabemos, la obra toda de Goya. Me refiero a algo que se va construyendo como un rasgo propio de su vida de artista: la diferencia, distancia o contraposición entre lo que concibe y produce para que sea contemplado por un público determinado (sea en la mansión de los duques de Osuna, en el Palacio Real, en el palacio de la duquesa de Alba o de otros aristócratas, en las paredes de una iglesia o una ermita, difundido a través de la reproducción mecánica) y lo que concibe en principio solo para ser contemplado, mirado, observado por sí mismo (y tal vez por alguno o algunos amigos). Y ahí podemos hallar una explicación para entender que no se pueden comparar el dibujo que pergeña para que se haga una estampa que irá (o debería ir) en la edición académica y el dibujo-apunte

70 Me refiero a Russell P. SEBold, Trayectoria del romanticismo español, Barcelona, Crítica, 1983; véase, a título de ejemplo, la discusión de sus ideas en Valeriano Bozal, Goya y el gusto moderno, Madrid, Alianza Forma, $2^{a}$ ed., 2002, págs. 19-65. Frente a la clara formulación de Sebold, que no duda de la presencia de la cosmovisión y consecuente estética contradictoria del Romanticismo en el último cuarto del siglo XVIII, otros historiadores han defendido un concepto de la sensibilidad neoclásica que casi se identifica con la romántica, pero que no lo es.

71 Schmidt, The Canonization, pág. 175.

72 Sснмidт, «Nuevas aportaciones», t. 1, pág. 443.

73 Morigno, «La visión de don Quijote», págs. 166-168. 
que traza para sí mismo, para su archivo personal, para su conjunto privado de detalles que marcará o posibilitará un posible retorno a la reflexión o el reciclaje. Es esa separación entre lo público y lo privado lo que construye Goya a lo largo de su vida y que estas dos versiones del Quijote ilustran magníficamente. Pero también podemos sugerir una línea de continuidad: la del espíritu crítico que - ausente de la estampa para la edición académica — marca los Caprichos, incluido el 43, que pone en relación el sueño y la razón, con el dibujo del álbum $\mathrm{F}$, en el que la figura del caballero mira frontalmente al espectador acompañado de las imágenes que hablan, no de su locura, sino más bien de la locura de los duques, perfectamente articulada en sus andanzas por la Segunda parte, y sobre todo que nos muestra a don Quijote como el cuidadoso lector de sus propias aventuras. 